\title{
Revalidation of Acanthagrion cuyabae (Odonata, Coenagrionidae) and description of the female, with a key to the Brazilian species of the viridescens group
}

\author{
Luiz Onofre I. de Souza ${ }^{1}$, Janira M. Costa ${ }^{2} \&$ Tatiana C. Santos ${ }^{2}$ \\ 1. Departamento de Biologia/CCBS, Universidade Federal de Mato Grosso do Sul, Cidade Universitária s/n, 79070-900 Campo Grande, \\ MS, Brazil. (irineudesouza@gmail.com) \\ 2. Departamento de Entomologia, Museu Nacional, Universidade Federal do Rio de Janeiro, Quinta da Boa Vista, São Cristóvão, 20940- \\ 040 Rio de Janeiro, RJ, Brazil. (jcosta@globo.com)
}

\begin{abstract}
Acanthagrion cuyabae Calvert, 1909 was described based on a male from State of Mato Grosso, Brazil. The female of this species was described based on morphological characters of four individuals collected in copula from State of Mato Grosso do Sul, and three other specimens of same locality. Acanthagrion cuyabae is here revalidated based on morphological characters of the female. Illustrated keys to the groups of Acanthagrion Selys, 1876 and species of the viridescens group occurring in Brazil are provided.
\end{abstract}

KEYWORDS. Acanthagrion, taxonomy, identification key, Brazil.

RESUMO. Revalidação de Acanthagrion cuyabae (Odonata, Coenagrionidae) e descrição da fêmea, com chave para as espécies brasileiras do grupo viridescens. Acanthagrion cuyabae Calvert, 1909 foi descrita com base em um macho do estado de Mato Grosso, Brasil. Descreve-se a fêmea desta espécie com base na análise de caracteres morfológicos de quatro indivíduos coletados em cópula em Mato Grosso do Sul e três outros exemplares da mesma localidade. Acanthagrion cuyabae é aqui revalidada com base nos caracteres morfológicos da fêmea. Chaves ilustradas para os grupos de espécies de Acanthagrion Selys, 1876 e espécies do grupo viridescens ocorrentes no Brasil são fornecidas.

PALAVRAS-CHAVE. Acanthagrion, taxonomia, chaves de identificação, Brasil.

Acanthagrion was created by SELYS-LongChAMPS (1876) with nine species, two varieties and three races. CALVERT (1909) described nine species for the genus, including A. cuyabae and its two subspecies: freirense and fimense. LEONARD (1977) distributed the species in nine groups: ablutum, abunae, adustum, apicale, ascendens, chararum, rubrifrons, viridescens and yungarum. The viridescens group included A. lancea Selys, 1876, A. peruanum Schmidt, 1942, A. gracile (Rambur, 1842), A. peruvianum Leonard, 1977, A. truncatum Selys, 1876 and A. viridescens Leonard, 1977. LEONARD (1977) considered A. cuyabae, and its two subspecies as synonyms of A. lancea. JuRzITZA (1980) described A. leonardi (viridescens group) and SCHORR et al. (2007) considered A. leonardi and A. cuyabae to be synonyms of $A$. lancea. GARRISON (2007) considered $A$. leonardi as a synonym of $A$. cuyabae, which he considered to be valid. Although the confusion regarding the status of A. cuyabae still remains today, we believe that the description of the female of this species can clarify the problem, thus A. cuyabae is a valid species.

\section{MATERIAL AND METHODS}

Wing venation terminology follows RIEK \& KuKalova-PeCK (1984). Illustrations were made with the aid of a camera lucida attached to a stereoscopic microscope; measurements are in millimeters; total length and abdominal length include appendages. The figures 8-30 do not have scale, had been removed of LEONARD
(1977), except figure 18. Abbreviations used throughout the text: FW, forewing; $\mathrm{HW}$, hindwing; $\mathrm{IR}_{2}$, radial sector; $\mathrm{RP}_{1}$, first branch of media; Pxn, posnodal crossvein; MNRJ, Museu Nacional, Universidade Federal do Rio de Janeiro; UFMS, Coleção Zoológica de Referência da Universidade Federal de Mato Grosso do Sul, Brazil.

\section{Acanthagrion cuyabae Calvert, 1909, revalidated (Figs. 1-7)}

Acanthagrion cuyabae CALVERT, 1909:166, figs. 83-86; Oౌ, type locality: Brazil, Mato Grosso State, Cuiabá, holotype in Carnegie Museum of Natural History, Pittsburg; LEONARD (1977) as a junior synonym of A. lancea Selys, 1876; Lencioni (2006):59, fig. 9; GARRISON (2007):34; Von ELLENRIEDER \& LONZANO (2008):100,101.

Diagnosis. The males of Acanthagrion cuyabae differs from other species of genus Acanthagrion by superior appendages shorter than S10 and inferior appendages shorter than the superior, each curved strongly upward in its distal half. The female of this species described here, differs of the others known Acanthagrion females by (characters for other species in parenthesis): quadrangular interlaminal sinus (triangular) and mesepisternal fossae as long as wide (longer than wide).

Material examined. BRAZIL. Mato Grosso do Sul: Corumbá (Base de Estudos do Pantanal-UFMS (S19³4'37", W57 01'06"-Datum WGS 84)), 7 \%, 23 ○', 20.X.2005 (MNRJ); 3 , same date (MNRJ); 10', same data, but 14.X.2005 (UFMS); $2 \sigma^{2}$, same data but 16.X.2005 (UFMS); $4 \sigma^{2}$, same date but 
19.X.2005 (UFMS); 3 O’, same date but 20.X.2005 (UFMS), all J. M. Costa \& L. O. I. Souza leg.; Mundo Novo, 2 \&, 26.V.2005, 29.IX.2005, L. Donizethe leg. (UFMS); Campo Grande, $4 \sigma^{7}$, 24.X.2000, A. Ribas leg. (UFMS); Terenos, 7 क', 2002, T. Moretti leg. (UFMS); Dourados, 1 †, 2 ○’, IX.2002, L. O. I. Souza leg. (UFMS).

Female. Similar to the male but with the following differences: head olive green dorsally, black in male; labrum, mandible and gena greenish, bluish in male; first antennal segment with green spot, bluish in male.

Prothorax blackish dorsally and pale laterally, mesepisternum bluish with a pale brown longitudinal stripe and a small black spot at the end of the mesopleural suture. Interlaminal sinus slightly quadrangular; mesepisternal fossae adjoining interlaminal sinus, as long as wide, forming a blunt triangle convex posterolaterally (Fig. 1). Legs yellowish, femora and tibia with a brownish longitudinal stripe, tarsi dark brown, claws black.

Wings with membrane hyaline; pterostigma light brown; $71 \frac{1}{2}$ Pxn crossveins in the FW, 7 Pxn in HW. $\mathrm{RP}_{2}$ arising at $\mathrm{Pxn}_{7}$. Variations: wings. - FW: $71 \frac{1}{2}-91 \frac{1}{2} \mathrm{Pxn}$; HW: 7 - 8 Pxn; $\mathrm{Rp}_{2}$ arising nearest $\mathrm{Pxn}_{4}$ in FW and nearest fifth in $\mathrm{HW} ; \mathrm{IR}_{2}$ arising at seventh/eighth Pxn.

Abdomen (Fig. 2) greenish with black pattern as follows: tergite I-VII black dorsally; VIII blue, with a black spot on $2 / 3$ of segment; IX anterior margin with a transverse black stripe interrupted mediodorsally; VIII and IX with a lateral blackish spot; lateral margin of sternites pale; stylus of ovipositor and vulvar spine of segment VIII brownish; anal appendages dark brown; valves of segment IX yellowish.

Measurements.Total length 32.02; length of FW 18.00; length of HW 17.00; abdomen 24.00. Variations (Max./Min.): total length 32.02 - 32.06; length of FW 18.00 19.00; length of HW 17.00-18.00; abdomen 24.00-26.00.

Habitat. All specimens from Corumbá were caught in temporary ponds with grass or aquatic macrophytes, in the Pantanal flood plain. The others specimens were collected in permanent or temporary ponds with grass and aquatic macrophytes.

Distribution. Bolivia, Brazil: Mato Grosso (Chapada, Cuiabá), Mato Grosso do Sul (Campo Grande, Corumbá, Dourados, Mundo Novo, Terenos).

Key to Acanthagrion species groups occurring in Brazil (adapted from LEONARD, 1977)

Females

1. Tibial spurs longer than space separating them .......... (rubrifons group)

1'. Tibial spurs shorter than space separating them ......2

2. Mesostigmal laminae diagonally transversed by a strong fold (Fig. 8) (abunae group)

2'. Mesostigmal laminae lacking a transverse fold ......... 3

3. Portion of mediodorsal carina separating mesepisternal fossae elevated, forming a broad-topped tubercle (Fig. 9) (apicale group)

3'. Portion of mediodorsal carina separating mesepisternal fossae elevated or not, if elevated always narrow
4. Interlaminal sinus rectangular, the transverse axis about twice the longitudinal axis; mesepisternal fossae tear-shaped, separated from posterior end of sinus (Fig. 10) (chararum group)

4'. Interlaminal sinus triangular, if rectangular, then the transverse axis equal to or shorter than longitudinal axis

5. Interlaminal sinus subplanate, median line a narrowly impressed groove, if concave, then fossae separated from posterior end of sinus by more than their own length, their long axis parallel to medium dorsal carina (Fig. 11) (ascendens group)

5'. Interlaminal sinus concave, V-shaped in cross section; fossae separated from posterior end of sinus by less than their own length or, if by more than this distance, their long axis transverse to medium dorsal carina

6

6. Mesostigmal fossae encroaching on interlaminal sinus; longitudinal axis of interlaminal sinus about $1 \frac{1}{2}$ the distance between mesostigmal laminae (Fig. 12) ... (adustum group)

6'. Mesostigmal fossae not encroaching on interlaminal sinus, if encroaching, then longitudinal axis of interlaminal sinus almost equal or shorter than distance between mesostigmal laminae (Fig. 13) ... (viridescens group)

Males

1. Tibial spurs longer than space separating them ......... (rubrifons group)

1'. Tibial spurs shorter than space separating them .......2

2. Inner surface of distal segment of genital ligula armed with hooks (Fig. 19) ..................... (abunae group)

2 '. Inner surface of distal segment of genital ligula not armed with hooks

3. Dorsum of abdominal segment 10 produced to form two posteriorly directed horns (Fig. 20)

(apicale group)

3'. Dorsum of abdominal segment 10 without horns ....4

4. Cerci dorsally directed (Fig. 21) ..... (chararum group)

4'. Cerci ventrally directed

5. Abdominal segment 10 much higher than 9 (Fig. 22); inner and outer surfaces of cerci uniform in color and surface texture ..................(ascendens group)

5'. Abdominal segment 10 in the same height as or lower than 9; if higher, inner face of cerci differing in color and surface texture from outer face ...................... 6

6. Distal edge of distal segment of genital ligula incised, terminal lobes directed onward (Fig. 23)

(adustum group)

6'. Distal edge of distal segment of genital ligula not incised, terminal lobes not directed onward (Fig. 24) ........

(viridescens group)

Key to the viridescens group species

Females

1. Longitudinal axis of interlaminal sinus longer than transverse distance between mesostigmal laminae 
1'. Longitudinal axis of interlaminal sinus shorter than transverse distance between mesostigmal laminae

2. Mesepisternal fossae adjoining but not encroaching on interlaminal sinus; lateral margins of posterior third of interlaminal sinus approximately parallel sided (fig. 14)

A. gracile (Rambur, 1942)

2'. Mesepisternal fossae widely separated of interlaminal sinus; lateral margins of posterior third of interlaminal sinus convergent (fig. 15)

A. peruvianum Leonard, 1977

3 . Longitudinal axis of interlaminal sinus longer than $1 / 2$ (about $2 / 3$ ) of the distance between mesostigmal laminae (Fig. 16)

3'. Longitudinal axis of interlaminal sinus $1 / 2$ of the distance between mesostigmal laminae (Fig. 17).

4. Mesepisternal fossae encroaching strongly on interlaminal sinus; posterolateral margins of sinus sharply concave (Fig. 16)

A. viridescens Leonard, 1977

4'. Mesepisternal fossae separated from interlaminal sinus; postero-lateral margins of sinus smoothly convex (Fig. 13) A. lancea Selys, 1876

5. Mesepisternal fossae much longer than wide, with concave posterolateral margins (Fig. 17)

A. truncatum Selys, 1876

5'. Mesepisternal fossae as long as wide, with convex posterolateral margins (Fig. 18)

A. cuyabae Calvert, 1909

Males

1. Cerci, in dorsal view, about $2 / 3$ of the length of segment 10 (Fig. 4); distal end of inferior appendages, in lateral view, shortness and expanded, not forming a hook (Fig. 3)

A. cuyabae Calvert, 1909

1'. Cerci, in dorsal view, almost equal to the length of segment 10; distal end of inferior appendages, in lateral view, tapering progressively to form a hook (Fig. 25)

2

2. Cerci, in lateral view, strongly directed downwards, mediodistal end not constricted (Fig. 26) ........... 3

2'. Cerci, in lateral view, slightly directed downwards,

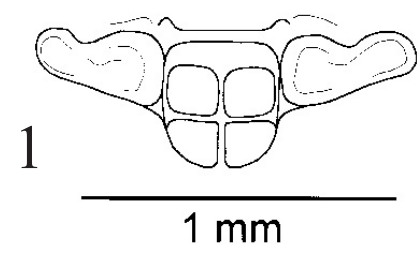

3

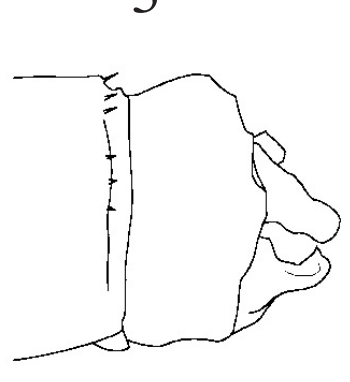

4
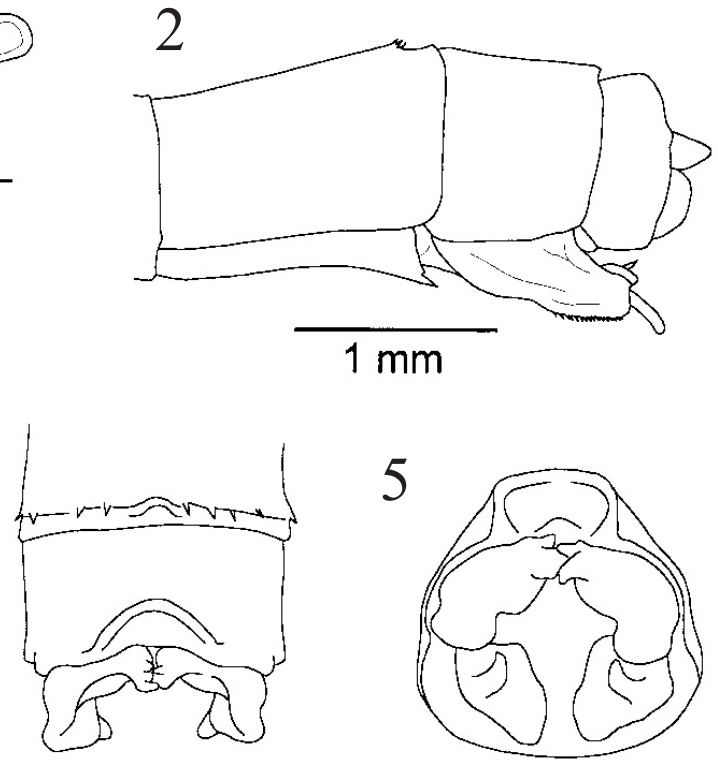

$1 \mathrm{~mm}$

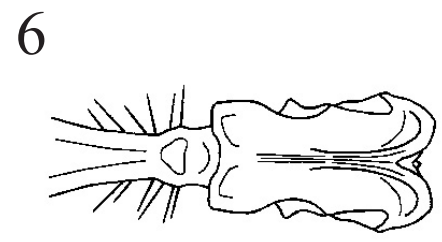

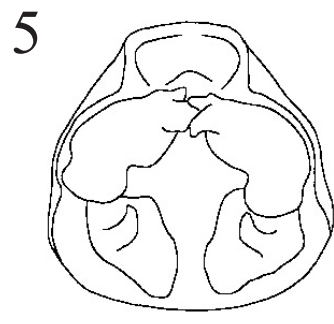

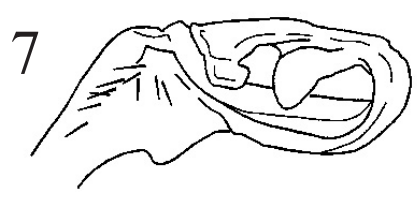

\section{$0.5 \mathrm{~mm}$}

Figures 1-7. Acanthagrion cuyabae Calvert, 1909. 1, 2, female: 1, interlaminal sinus and mesepisternal fossae, dorsal view; 2, abdominal segments 8-10, lateral view; 3-7, male: 3 , abdominal segment 10, lateral view; 4, abdominal segment 10, dorsal view; 5, abdominal segment 10 , posterior view; 6 , genital ligula, ventral view; 7 , genital ligula, lateral view. 


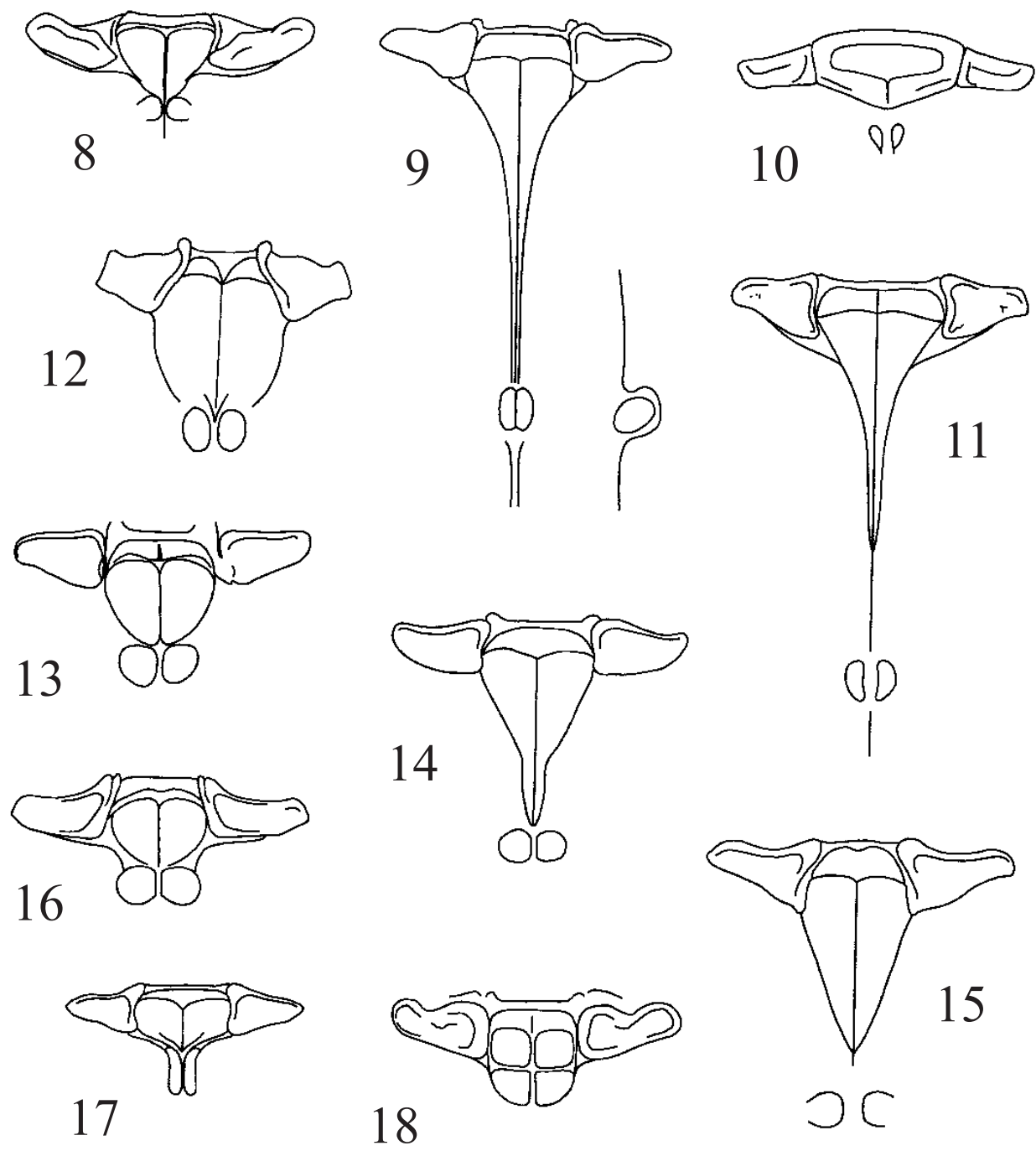

Figures 8-18. Females, interlaminal sinus and mesepisternal fossae, dorsal view: 8, Acanthagrion temporale Selys, 1876; 9, A. apicale Selys, 1876; 10, A. chararum Calvert, 1909; 11, A. ascendens Calvert, 1909; 12, A. adustum Williamson, 1916; 13, A. lancea Selys, 1876; 14, A. gracile (Rambur, 1942); 15, A. peruvianum Leonard, 1977; 16, A. viridescens Leonard, 1977; 17, A. truncatum Selys, 1876; 18, A. cuyabae Calvert, 1909 (all figures from LeONARD (1977), except figure 18, without scales).

mediodistal end constricted; dorsal edge sinuous (Figs. 25, 29) ... 4

3. Cerci with dorsal edge almost straight (Fig. 26) .........

3'. Cerci with dorsal edge sinuous (Fig. 30) A. gracile (Rambur, 1842) A. peruvianum Leonard, 1977

4. Distal tip of genital ligula narrow (Fig. 27) A. truncatum Selys, 1876

4'. Distal tip pf genital ligula wide (Fig. 28) 5

5. Notch of lateral lobes of distal genital ligula segment plainly visible ventrally (Fig. 28); dorsal tubercle of cerci weakly developed (Fig. 25); predominant light colour, blue A. lancea Selys, 1876 5'. Notch of lateral lobes of distal genital ligula segment barely visible ventrally (Fig. 24); dorsal tubercle of cerci prominent (Fig. 29); predominant light colour green A. viridescens Leonard, 1977

\section{DISCUSSION}

Based on cerci shape A. cuyabae shows close affinities to $A$. lancea but differs by (characters for $A$. lancea in parenthesis): cerci about $2 / 3$ of segment 10 length (almost equal), with internal border forming an acute angle (obtuse), distal end of inferior appendages, in lateral view, not forming a defined hook (forming a defined hook), end of genital ligula distal lobe wide (narrow) and median lobes, not visible in lateral view (visible).

Based on the male LEONARD (1977) and more recently SCHORR et al. (2007) stated that A. cuyabae is a syonym of A. lancea whereas GARRISON (2007) and VON ELLENRIEDER \& LONZANO (2008) consider it a valid species. The study of the female morphology settles the controversy confirming that is a valid species. 


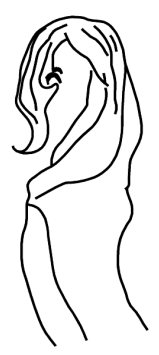

19

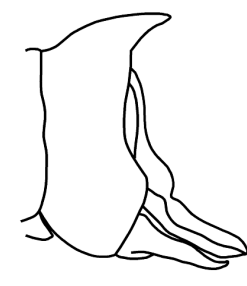

20

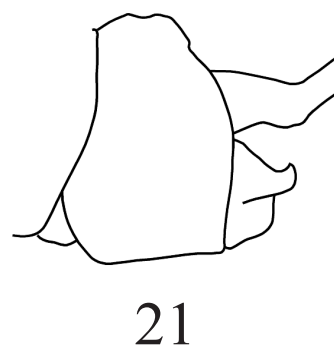

21
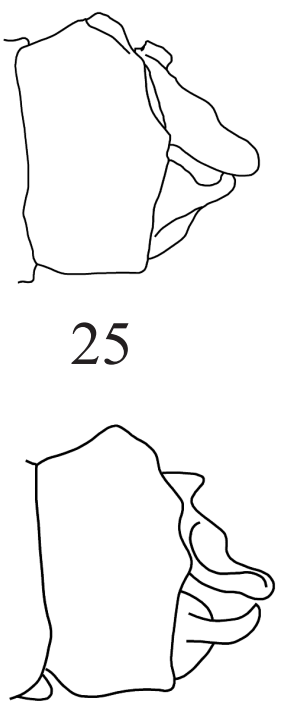

29

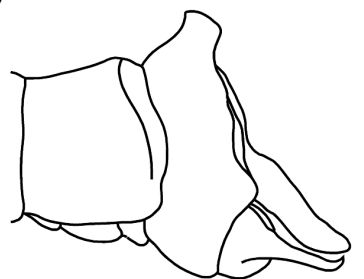

22

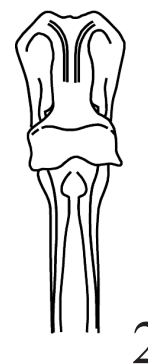

23

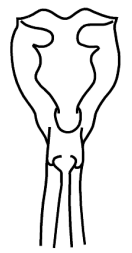

27

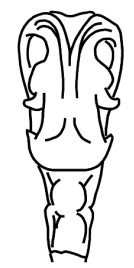

28

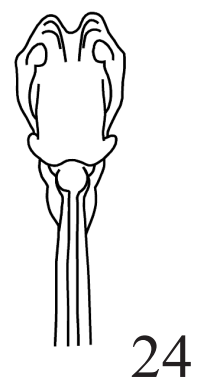

Figures 19-30. Males: 19, Acanthagrion temporale Selys, 1876, genital ligula, lateral view; 20, A. apicale Selys, 1876, segment 10, lateral view; 21, A. chararum Calvert, 1909, segment 10, lateral view; 22, A. ascendens Calvert, 1909, segment 10, lateral view; 23, A. adustum Williamson, 1916, genital ligula, ventral view; 24, A. viridescens Leonard, 1977, genital ligula, ventral view; 25, A. lancea Selys, 1876, segment 10, lateral view; 26, A. gracile (Rambur, 1942), segment 10, lateral view; 27, A. truncatum Selys, 1876, genital ligula, ventral view; 28, A. lancea, genital ligula, ventral view; 29, A. viridescens, segment 10, lateral view; 30, A. peruvianum Leonard, 1977, segment 10, lateral view (all figures LEONARD (1977), without scales).

Acknowledgments. We are very gratefull to Dr. Ângelo B. M. Machado (UFMG) for his critical revision of this manuscript. This research was supported by Conselho Nacional de Desenvolvimento Científico e Tecnológico (CNPq), Universidade Federal do Rio de Janeiro (UFRJ), Universidade Federal de Mato Grosso do Sul (UFMS) and Universidade Federal da Grande Dourados (UFGD) - Programa de Pós-graduação em Entomologia e Conservação da Biodiversidade.

\section{REFERENCES}

Calvert, P. P. 1909. Contributions to knowledge of the Odonata of the Neotropical Region exclusive of Mexico and Central America. Annals of Carnegie Museum 6:73-280.

GARRISON, W. R. 2007. Dragonfly and Damselfly New World Catalogue. Available at: <http://odonatacentral.bfl.utexas.edu/ utilities/catalog/>. Accessed on: 03.09.2009.

JuRZITZA, G. 1980. Acanthagrion leonardi spec. nov. aus Iguazú, Misiones, Argentinien (Zygoptera: Coenagrionidae). Odonatologica 9(2):181-184.
Lencioni, F. A. A. 2006. Damselflies of Brazil: an illustrated guide. II - Coenagrionidae. São Paulo, All Print. v.2, 419p.

LeONARD, J. W. 1977. A Revisionary Study of the Genus Acanthagrion (Odonata: Zygoptera). Miscellaneous Publications. Museum of Zoology, University of Michigan 153:1-154.

Riek, E. F. \& Kunalova-Peck, J. 1984. A new interpretation of dragonfly wing venation based upon Early Upper Carboniferous fossils from Argentina (Insecta: Odonatoidea) and basic character states in pterygote wings. Canadian Journal of Zoology 62(6): 1150-1166.

Selys-Longchamps, E. 1876. Synopsis des Agrionines, cinqüième légion: Agrion (suite). Le Grand Genre Agrion. Bulletin de l’Academie Royale Sciences de Belgique 41(2):247-322, 496-539.

Schorr, M.; Lindeboom, M. \& Paulson, D. 2007. World Odonata List. Available at: 〈http://www.ups.edu/x6145.xml〉. Accessed on: 03.09 .2009 .

Von EllenRIEDER, N. \& LonZANo, F. 2008. Blues for the red Oxyagrion: a redefinition of the genera Acanthagrion and Oxyagrion (Odonata: Coenagrionidae). International Journal of Odonatology 11(1):95-113.

Recebido em janeiro de 2008. Aceito em agosto de 2009. ISSN 0073-4721

Artigo disponível em: www.scielo.br/isz 